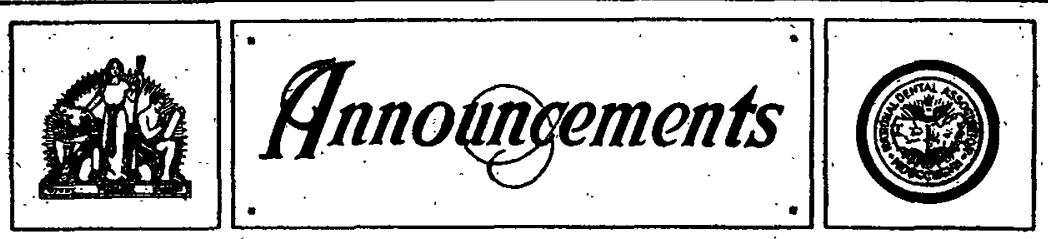

NATIONAL DENTAL ASSOCIATION, 1920.

Aúgust.

23-24-25-26-27-Boston.

April.

5-7-American Society of Orthodontia, Chicago, IIl.

\section{STATE SOCIETIES.}

March.

4:5-6-Minnesota, Minneapolis. 8-9-10-11-12-13-Texas, Dallas.

15-16-17-18-19-20-Oklahoma, Tulsa.

17-18-19-Vermont, Burlington.

22-23-24-25-Illinois, Chicago.

22-23-24-25-26-27-Kansas, Wichita.

29-30-31, April 1-2-3, South Dakota, Sioux Falls.

\section{April.}

7-8-9-Kentucky, Louisville.

12-13-14-Michigan, Detroit.

12-13-14-Missouri, Kansas City.

13-Alabama, Mobile.

14-15-16-West Virginia, Charleston.

19-20-21-22-23-Mississippi, Jackson.

20-21-22-Connecticut, New Londen.

27-28-29-Pennsylvania, Reading.

\section{May,}

Massachusetts, Boston.

North Dakota, Grand Forks.

4-5-6-Iowa, Cedar Rapids.

9-10-11-New York, Albany.

17-18-19-20-21-22-Nebraska, Lincoln.

18-19-20-Indiana, Indianapolis.
June.

Florida, Miami.

Maryland, Báltimore.

Maine.

New Hampshire, Manchester.

New Mexico, Albuquerque.

Southern California, Los Angeles.

South Carolina, Columbia.

Utah, Provo.

9-10-11-Georgia, Atlanta.

14-Colorado, Colorado Springs.

14-15-Wyoming, Cheyenne.

29-30, July 1-2, North Carolina Wrights-

ville Beach.

$$
\text { July. }
$$

New Jersey.

Virginia, Old Point Comfort.

13-14-15-Wisconsin, Milwaukee.

\section{November.}

18-District of Columbia, George Washington University, Washington, D. C.

Árizona, Phoenix.

December.

2-3-4-Ohio, Columbus.

10-Delaware, Wilmington.

Dates to Be Announced.

Arkansas, Little Rock.

California State.

Idaho, Pocatello.

Louisiana, New Orleans.

Montana, Great Falls.

Oregon, Portland.

Tennessee, Chattanooga.

Washington, Tacoma. 
ILLINOIS STATE DENTAL SOCIETY.

The fifty-sixth annual meeting of the Illinois State Dental Society will be held in the Congress Hotel, Chicago, March $22,23,24$ and $25,1920$.

The following essayists have been secured: Dr. Alfred C. Fones, Bridgeport, Coun.; Dr. Charles S. Essig, Philadelphia, Pa.; Dr. Wm. H. G. Logan, Chicago; Dr. Newton G. Thomas, Chicago; Dr. Hart J. Goslee, Chicago; Dr. F. E. Roach, Chicago; Dr. K. W. Knapp, Des Moines, Iowa; D. A. A. Herdliska, United States Public Health Service, Washington, D. C.

A most cordial invitation is extended to all ethical practitioners in Illinois and neighboring states.

G. WALTER DITTMAR, Pres.

J. P. LUTHRINGER, Secy.

\section{OKLAHOMA STATE DENTAL SOCIETY}

The next meeting of the Oklahoma State Dental Society will be held in Tuisa, Oklahoma, March 15-16-17-18-19-20, 1920. This meeting will be conducted on the class system of post graduate instruction.

The attendance will be divided into classes, by enrollment previous to the time of the meeting and each class will take up the intensive study of one subject for the full week.

At this time the following teachers have been engaged:

Dr. Thos. B. Hartzell, Pyorrhea and Prophylaxis.

Dr. Arthur E. Smith, Nerve Blocking and Anesthesia.

Dr. Dayton D. Campbell, Full Dentures.

Dr. F. E. Roach, Partial Removable Dentures.

Dr. T. W. Maves, Inlays and Abutments for Vital Teeth.

These teachers will have assistants to help with the class work. The instruction will consist of lectures, technical and practical demonstrations. Ample facilities will-be provided for clinical in- struction and where possible the stiudents of each class will be expected to do much of the practical work.

This meeting is one of a chain of meetings to be conducted by the Texas, Kansas, South Dakota and Oklahoma State Dertal Societies. Any dentist, in good standing in his state society with 1920 dues paid, desiring to attend this meeting will be permitted to do so, provided the class of his choice is not filled by our own members. The class fee is fifty dollars.

The Bulletin of the Oklahoma State Dental Society, which gives full information about our meeting will be mailed to any one upon request.

C. R. LAWRENCE, General Manager, Stephenson Bldg., Enid, Okla.

\section{PENNSYLVANIA STATE DENTAL SO- CIETY.}

The fifty-second annual meeting of the Pennsylvania State Dental Society will be held in the Rajah Theatre, Reading, Pa., April 27, 28 and 29, 1920. An interesting and instructive program has been prepared. All ethical practitioners are invited to be present.

W. L. FICKES, Sec'y, 6004 Penn Ave., Pittsburgh, Pa.

\section{HOME COMING, ALUMNI ASSOCIA- TION, WASHINGTON UNIVERSITY.}

Are you planning to attend the Home Coming of the Alumni Association of Washington University School of Dentistry, February 23-24? There will be practical demonstrations as well as individual clinics and clinics of the St. Louis Study Club. This meeting promises to be the best and most interesting ever held, so : help yourself and the Alumni Association by being present.

A. 'VERNETTE SANDUS;",

Publication Committee, St. Louis, Mo. 


\section{SOUTH DAKOTA STATE DENTAL SOCIETY.}

The 38th annual meeting of the South Dakota State Dental Society will be held in Sioux Falls, March 29 to April 3, 1920. One week of post graduate instruction will be given under the following clinicians:

Dr. Arthur E. Smith, Chicago, Ill.

Dr. F. Ewing Roach, Chicago, Ill.

Dr. Dayton Dunbar Campbell, Kansas City, Mo.

Dr. T. W. Maves, Minneapolis, Minn. ERNEST W. ELMEN, Secretary, 608 S. F. National Bank Bldg., Sious Falls.

\section{MASSACHUSETTS STATE BOARD OF DENTAL EXAMINERS.}

The next meeting of the Massachusetts State Board of Dental Examiners will be held in Boston, Mass.; March 10th, 11th, 12th and 13th, 1920, beginning promptly at 9:30 A. M., March 10th.

All applications must be in the hands of the Secretary by March 1st. Fee for examination, $\$ 20.00$. Full information and application blanks may be received by addressing

J. N. CARRIERE, D. D. S., Secy., 352 Main Street, Fitchburg, Mass.

\section{TWENTY-FOURTH ANNUAL MEETING}

\section{National Dental Association, Boston, Mass., August 23-27, 1920.}

"Listen my children and you shall hear, Of the Midnight Ride of Paul Revere."

So runs the masterful poem of Henry Wadsworth Longfellow that has so thrilled us in our school days, but you say what has this to do with dentistry?

Paul Revere organized, and was elected First President of the Massachusetts Mechanics Association and this association erected the famous Mechanics Building, which is known all over the con- tinent as the home in Boston, Mass., of the far famed poultry shows, automobile and dog shows, mechanics and food fairs, and athletic meets.

Massachusetts Mechanics Building is 600 feet in length, covers three acres of land, and contains over 150,000 square feet of floor space, being one of the largest buildings in the United States for exhibition purposes of every description.

August 23-24-25-26-27, 1920, the Mechanics Building Boston, Mass., will be the home of the National Dental Association, conducting the biggest, busiest, and best dental meeting ever held in the history of dentistry. The many halls on the second floor, make it ideal for a Seminar Course meeting, which is the plan of the committee for this year. While the almost unlimited floor space of the grand exhibition hall on the main floor, will afford ample room that all manufacturers may exhibit to any extent they desire, and assures the finest exhibit of dental materials and specialties, ever gathered together under one roof in this or any other country.

This building contains many relics of historic interest to all who will attend this meeting, and the committee in charge is all ready at work, making arrangements to care for six thousand members of the profession, while the entertainment committee has mapped out a program for the entertainment of the ladies, exceeding anything ever before attempted at the National Dental As. sociation meetings.

F. E. JEFFREY, Chairman, Publicity Committee National Dental Association.

\section{VERMONT STATE DENTAL SOCIETY.}

The Vermont State Dental Society will hold its next annual meeting in Burling. ton on Wednesday, Thursday and Friday, March 17 to $19,1920$.

PHILIP E. MELLEN, Secretary, Middlebury, Vermont. 
CHICAGO DAY, TUESDAY, MARCH 23,
1920.

During the Illinois State Dental Society Meeting.

The Illinois State Dental Society's annual meeting will be held in the Congress Hotel, Chicago, Illinois, March 2225, 1920. Tuesday, March 23, has been given over to the Chicago Dental Society and will be known as CHICAGO DAY. The program for this day will be under the auspices of the officers of the Chicago Dental Society. The entire day, both forenoon and afternoon, will be devoted to clinics, while the evening program will consist of a banquet in honor of Dr. Thomas L. Gilmer. Some new plans will be inaugurated in staging the clinic.

\section{Ten Sectional Unit Clinics.}

1. There will be ten sectional unit clinics with forty clinicians. The clinics will be given in the nature of a lecture and demonstration on the live subjects before the dental profession of today.

2. Two clinicians from each sectional unit will lecture and demonstrate in the morning and a like number will follow in the afternoon. However, each clinician will lecture and demonstrate his own particular technic.

3. The forty clinicians that have been invited to participate in these clinics are men of national reputation in the field they are to demonstrate.

4. Ample space has been secured so that everyone may have an opportunity to see this novel clinic manned by such an unusual galaxy of talent.

5. The only clinic given during the annual meeting of the Illinois State Dental Society will be given by the Chicago Dental Society on Tuesday, March 23.

Banquet to Thomas L. Gilmer.

The program committee of the Chicago Dental Society has arranged to give to Dr. Thomas L. Gilmer a testimonial banquet. This banquet will be held on Tues- day evening-CHICAGO DAY-in the Gold Room of the Congress Hotel. Men of national and international reputation have accepted invitations to attend this meeting and participate in the literary program. The program committee announces the following:

Dr. Edw. T. Darby, Philadelphia, Pa.

Dr. A. W. Thornton, Montreal, Canada.

Dr. John V. Conzett, Dubuque, Iowa.

Dr. Thos. P. Hinman, Atlanta, Ga.

Dr. Truman W. Brophy, Chicago, Ill.

Dr. Frank Billings, Chicago, Ill.

Dr. H. E. Friesell, Pittsburgh, Pa.

Dr. Arthur D. Black, Chicago, Ill.

Dr. G. Walter Dittmar, Chicago, Ill.

Dr. C. N. Johnson, Chicago, Ill.

Dr. Frederick B. Noyes, Chicago, Ill.

Dr. H. J. Burkhart, Rochester, N. Y.

The officers of the Chicago Dental Society are putting forth every effort to make CHICAGO DAY stand out in bold relief as one of the hig days in the history of dentistry in Iilinois.

VICTOR H. FUQUA, President, 25 E. Washington St., Chicago, Ill.

\section{ALUMNI SOCIETY OF THE DEWEY SCHOOL OF ORTHODONTIA.}

The next annual meeting of this society will be held on April 1-2-3, 1920, at the Edgewater Beach Hotel in Chicago.

The usual high standard of the meetings of this Society will be maintained. One half day will be devoted to clinics.

All interested in Orthodontia are cordially invited to attend these meetings.

GEORGE F. BURKE, Secretary. 741-45 David Whitney Bldg.

Detroit, Michigan.

\section{MINNESOTA STATE DENTAL ASSO- CIATION.}

The thirty-seventh annual convention of the Minnesota State Dental Association will be held at the West Hotel, Minneapolis, Minn., on March 4th, 5th and 6th, 1920. MAX E. ERNST, Secretary, 1125 Lowry Bldg., St. Paul, Minn. 
ANNUAL CONVENTION OF TEXAS STATE DENTAL SOCIETY.

The Texas State Dental Society will hold its 40 th annual convention on March $8-13,1920$, at Dallas, Texas. The special feature of this meeting will be postgraduate class courses conducted on the "Oklahoma Plan." These classes will be conducted by the following well known men: Dr. Thomas B. Hartzell, Minneapolis, Minn.; Dr. F. Ewing Roach, Chicago, Ill.; Dr. Arthur E. Smith, Chicago, Ill.; Dr. Dayton D. Campbell, Kansas City, Mö; Dr. 'T. W. Maves, Minneapolis, Minn. Other instructors may be employed.

J. G. FIFE, Secretary, 736 Wilson Bldg., Dallas, Texas.

\section{MISSISSIPPI DENTAL ASSOCIATION.}

The Mississippi Dental Association will hold its annual meeting at Jackson, April 19-23, 1920, inclusive.

\section{W. F. BEAVERS, Secretary,} Meridian, Miss.

\section{NOTICE.}

\section{Twelfth Annual Congress of the Ameri- can School Hygiene Association to be Held in Cleveland Febru- ary 24-25-26-27-28.}

The preliminary program of the 12th congress of the American School Hygiene Association to be held in Cleveland the latter part of February, has just been issued by its Secretary, Dr. "William A. Howe, of the State Department of Education, Albany, N. Y.:

This association is composed of prominent educators and health workers in varioüs' parts of America. The program as outlined will consist of nine one-half day sessions, beginning on Tuesday morning, February 24 , and closing on -Saturday morning, February 28.

All of the first day will be devoted to the consideration of Health Education. The entire second day will be devoted to School Health Service, including School Medical Inspection, Physical Education, School Nursing, and other activities under the general title of school health service. The session on Thursday morning will be devoted to Sex Education and Communicable Diseases. State Commissioner of Health, Freeman, of Ohio, is listed as chairman of this section. Thursday afternoon is given to the subject of nutrition of school children under the chairmanship of Dr. William R. P. Emerson, of Boston. On Friday morning seven papers on "Mouth Hygiene" will be presented by prominent dentists of this country and Canada. The full program of this section is given below. Friday afternoon will be devoted to Mental Hygiene under the Chairmanship of Dr. Henry H. Goddard, of Columbus, Ohio. The closing session on Saturday morning will be devoted to a symposium on the Relation of Health and School Authorities. Dr. Willard S. Small; of the U. S. Bureau of Education, is chairman of this section.

The entire program is filled with much valuable material and will prove, in our opinion, the most constructive and progressive contribution of recent years to our literature of School Health Service.

It is earnestly hoped that the dental profession of the country will avail itself of the opportunity, not only to hear the section devoted to Mouth Hygiene, but many others of the congress.

Membership in the association, which includes a copy of the proceedings of the congress, is $\$ 3.00$ Let the Secretary hear from you.

Friday Morning, 9:30.

Mouth Hygiene.

How can the National Dental Association aid in a program for better teeth and ketter health for school children?

Otto U. King, D. D. S.; Secretary National Dental Association. 
Teaching of Mouth Hygiene to School Children from the viewpoint of the Dental Journalist.

Rea P. McGee, M. D., D.D.S., Editor Oral Hygiene, Pittsburgh. The relation of good teeth, clean mouths, and good nutrition to good health (with film "Come Clean.")

Major L. G. Mitchell, U. S. A., Washington.

Oral Hygiene and its relation to all health educational activities.

Homer C. Brown, D. D.S., ExPresident, National Dental Ass'n, Columbus.

How can school children be taught preventive dentistry?

Eudore Dubeau, L. D. S., Ecole de Clirungie Dentaire de Montreal:

Children's work in the Rochester

Dental Dispensary and in the

Schools of Monroe County.

Harvey J. Burkhart, D. D. S., Rochester Dental Dispensary, Director.

Junior Red Cross and School Dental Ambulance. Service in rural communities in Nassau County.

Walter J. Multer, Supervising Principal Roslyn High School and Chairman Junior Red Cross Health Activities, Roslyn, L. I.

\section{AN APPEAL TO DENTISTS}

Cooperation in the Fight Against Venereal Diseases.

The war turned the spotlight on many things heretofore neglected or avoided. No disclosures were more startling than those showing the destructive inroads of ventreal disease on the health and efficiency of the Army and Navy.

From the time the United States entered the war in April, 1917, to September, 1918, the loss to the Army from venereal disease represented 2,295,000 days of service.
Now the war is over!

The Nation is on its way to a peace basis.

Interest begins to turn from the fighting efficiency of the Army to the reconstructive power of industry; and as it turns this striking fact stands' out: All venereal diseases in the Army were caused by conditions in civilian life. The Army and Navy, as organizations, do not tolerate prostitution.

Testimony of the Army.

Immediately following the declaration of war the Army Medical Department organized to cope with venereal disease, and one of the first points emphasized by its Surgeon General was that each individual case must be treated under competent medical supervision until cured. He laid special emphasis on two points :

1. The ineffectiveness of self-treatment by the use of simple or patent remedies.

2. The danger of quack doctors, who advertise to treat so-called private diseases.

Nineteen months of war have shown conclusively the value of proper methods of treating venereal cases in the Army.

Maintain Industrial Efficiency.

For the protection of the fighting men as they return home, and to maintain maximum industrial efficiency, venereal disease among the civilian population must be kept under control. There is the same necessity for proper methods of treatment as existed in the service. Self-treatment and quackery must go.

\section{Responsibility of Dentists.}

Dentists must share the responsibility for preventing the spread of syphilis. It is found in all walks of life, all classes of society, and it is too often not recognized when examinations of the mouth are made for dental treatment. Persons who have lesions in the mouth and know they have syphilis, and admit it, do not as a rule seek the services of a dentist unless 
compelled to do so. Those who have lesions and are unaware of their condition present themselves to the dentist unsuspectingly, and for that reason are a serious menace to the health of the dentist and his clientele.

The ease with which the disease is transmitted is well known to the members of the profession. A break in the skin or mucous membrane, a spirochete gaining entrance and passing into the circulation- and infection occurs. Syphilis is no respecter of persons; neither is it a respecter of tissues. The simple scaling of the teeth may, and usually does, involve a breaking in the continuity of gum tissue and exposes the patient to any infection carried on an unclean instrument. In view of the prevalence of syphilis and the difficulty with which the germ of this disease is destroyed, it is of the highest importance that dentists continue to study and practice the principles of asepsis in all phases of their work. It should be borne in mind that the saliva of those infected with syphilis is usually loaded with spirochetes, and that it is not necessary that blood be drawn from the patient in order to infect another thru the application of instruments.

Recognizing the various lesions found in the mouth, which are signs of definite diseases, requires clinical knowledge and experience. Many infectious diseases produce lesions in the mouth, and the stuuy of these lesions, which might enable the dentist to recognize such infection as well as the infection of syphilis, is extremely interesting and should be of material benefit to the dentist. It is believed that if the question of venereal diseases were discussed more freely and frequently in study clubs and dental societies, it would be a benefit to society and reflect credit on the dental profession.

Recent investigations have clearly proved that dental structures are an important part of the human economy. The man who treats his case symptomatically is most likely to fail. Dentists have been confronted with increased responsibility in the matter of general health, not merely because they have aspired to greater things, but because it has been thrust upon them, and the proposition must be met face to face.

\section{Cooperation of Physicians, Druggists, and Advertising Media.}

The campaign now being carried on among dentists is similar to those carried on with physicians, druggists, and advertising media. It should interest you to know that approximately 61,000 , or nearly 50 per cent, of the physicians of the United States, and that approximately 28,000 , or nearly 60 per cent, of the druggists of the United States, have signed and returned agreement cards obligating themselves to cooperate; and in addition to these, more than 99 per cent of all newspapers and periodicals in the United States carrying advertising have pledged themselves not to carry quack advertising

\section{Weigh These Questions.}

Will the dental profession accept its share of the burden which this work requires? On receipt of the inclosed franked card, properly signed, the Public Health Service will ask your State Board of Health to supply you with additional scientific and miscellaneous literature.

\section{RUPERT BLUE,}

Surgeon General, United States Public Health Service.

\section{MICHIGAN STATE DENTAL SOCIETY.}

The next meeting of the Michigan State Dental Society will be held at the Hotel Statler, Detroit, Mich., April 12, 13 and 14, 1920. The chairman of local arrangements is William $\mathrm{H}$. Waller, 613 Washington Arcade, Detroit.

CLAUDE S. LARNED, Secretary, 614 Post Bldg., Battle Creek, Mich. 
MISSOURI STATE DENTAL SOCIETY.

Meeting of the Missouri State Dental Association to be held at the Baltimore Hotel, Kansas City, Missouri, April 12, $13,14,1920$.

H. C. POLLOCK, Secretary, 724 Metropolitan Bldg., St. Louis, Mo.

SOUTHWESTERN DENTAL SOCIETY.

The third annual meeting of the Southwestern Dental Society will be held at El Paso, Texas, on Thursday, Friday and Saturday, March 4, 5 and 6, 1920. A cordial invitation is extended to practitioners of dentistry.

RAYMOND H. GUDGER, Secretary, Silver City, New Mexico.

\section{SIGMA EPSILON DELTA.}

The next regular meeting of the Grand Council of the Sigma Epsilon Delta Fraternity, will be held at the Hotel Astor, 44th Street and Broadway, New York City, on Tuesday, March 23rd, at $8: 30$ o'clock. Full representation from all chapters is requested.

By order of the Grand Council. ROBERT E. ELSTER, Master.

\section{KENTUCKY STATE DENTAL SO- CIETY.}

The next annual meeting of the Kentucky State Dental Association will be held in Louisvilie, April 7-8-9, 1920.

A program of unusual interest has been planned. Address all correspondence to W. M. Randall, Secy., 1035 Second St., Louisville, Ky.

\section{RECENT PATENTS OF INTEREST TO DENTISTS.}

1318254, Dental preparation and making the'same, Viggo V. J. Andresen, Copenhagen, Denmark.
1318266, Anesthetic dispenser, Harlon A. Clifford and J. W. Cobb, Greenfield, Mass.

1317980, Dental appliance, Ira Lee, Seattle, Wash.

1317886, Preparing amalgam for dentists' use, Wm. M. Muchow, Evanston, Ill.

1317832, Artificial tooth, Vernon Spencer, Mosman, New South Wales, Australia.

53903, Design, Amalgam remover, Frank L. Grier, Milford, Del.

53904, Design, Alloy-scoop, Frank L. Grier, Milford, Del.

53955, Design, Dental plastic instrument, Daniel A. Zurbrigg, Milford, Del.

53956, Design, Dental carving instrument, Daniel A. Zurbrigg, Milford, Del.

53957, Design, Dental burnisher, Daniel A. Zurbrigg, Milford, Del.

53958 Design, Dental trimming file,

Daniel A. Zurbrigg, Milford, Del.

1318522, Tooth-brush, Solomon Alexander, Long Beach, Cal.

1318351, Moistening attachment for dental handpieces, Ira A. Burnett, Chicago, Ill.

1318964, Tooth-brush, Benjamin Chess, New York, N. Y.

1318647, Rotary tooth-brush, Guy B. Collier, Kinderhook, N. Y.

1318751, Therapeutic lamp, John J. Heitz, Chicago, Ill.

1318757, Lighting fixture, Paul M. Hotchkin, Chicago, Ill.

1318783, Combined direct and indirect lighting fixtures, Earle C. McKinnie, Chicago, Ill.

1318586, Hypodermic syringe needle and base, Frank L. Platt, C. N. Hein, and R. R. Impey, San Francisco, Cal.

1318428, Combined tooth-brush holder and tumbler support, Frank E. J. Young, Chicago, Ill.

1319243, Hypodermic syringe, George G. Powers, Los Angeles, Cal.

1320133, Anchorage for dental bridges and plates, Steele F. Gilmore, Indianapolis, Ind. 
(1) 1320337, Artificial tooth, Simon Myerson, .. Cambridge; Mass.

1320275, Device for extruding paste from tubes, Edwin. G. Roach; New York, N. Y.

1319904, Combined mouth-gag and tongue depressor, Edwin L. Roberts, Nashville, Tenn.

1319737, Dental device and denture construction, Frank M. Wadsworth, Minneapolis, Minn.

1320324, Apparatus for casting dental inlays, Elpha E. Bailey, and J. H. Jacobs, Denver, Colo.

1320536, Automatic injection syringe, Raymond Di Falco and J. De Paul, EIIwood City, Pa.

1320616, Rotary tooth-brush, George S. Hampe, Alhambra, Cal.

1320583, Stand for dental articulators, Wm. M. Stanbrough, Newburgh, N. Y.

1321451, Multiple-jaw rubber-dam clamp, James W. Ivory, Philadelphia, Pa.

1321452, Rubber-dam punch, James W.

Ivory, Philadelphia, Pa.

1321465, Dental film holder, Rector P. MacLagan, Park Ridge, Ill.

1321137, Facial contour restorer, Francis M. Morgan, San Francisco, Cal.

1321124, Restoring teeth, Albert $D$. Pentz, Jr., New York, N. Y.

1321126, Anchor for artificial teeth, George W. Ramsey, Washington, D. C., and G. E. Fritz, Chicago, IIl.

1321129, Dental drill, Frank F. Schlueter, Watertown, Wis.

1321130, Dental drill, Frank F. Schlueter, Watertown, Wis.

1322413, Fountain tooth-brush, Jacob

H. Ekmekjian, Pasadena, Cal.

13222424, Forming metal backs for artificial teeth, Ernest Garden, Los Angeles, Cal.

1322355, Denture attachment and means for applying same, Herman Schreier, Sheboygan, Wis.

1322385, Dental articulator, Walter J. Wilson, Petersburg, Ind.

1322387, Motor-driven dental articulator, Walter J, Wilson, Petersburg, Ind.
1322994, Orthodontic appliance, Edward H. Angle, Pasadena, Cal.

1323042, Tooth-brush, Joseph A. Gardner, Memphis, Tenn.

1323161, Method and apparatus for administering anesthetics, Walter V. Goodfellow, Los Angeles, Cal.

1323037, Tooth-brush, Minor T. Holliday, Bozeman, Mont.

1323141, Orthodontia appliance, Jacob

L. Young, New Rochelle, N. Y.

Copies of above patents may be obtained for twenty-five cents each, by addressing John. A. Saul, solicitor of Patents, Fendall Building, Washington, D. C.

\section{DENTAL CORPS ORDERS FROM WAR DEPARTMENT.}

\section{DENTAL CORPS.}

Maj. Neal A. Harper to Governors Island, N. Y., for duty.

Capt. Arthur T. Burchill to Montgomery, Ala., aviation repair depot, for duty.

First Lieut. Harold S. Whitney to Carlisle, Pa., general hospital 31, for duty. -Army and Navy Register, December 6.

The following honorary discharged is colonels only: Cols. Samuel H. I.eslie and Frank P. Stone.

Lieut. Col. E. Henry Valentine to Camp Jackson, S. C., for duty.

The following honorably discharged as lieutenant colonels only: Lieut. Cols. Lee $\mathbf{s}$. Fountain, E. Henry Valentine and Charles M. Taylor.

Maj. John L. Schock and Capt. Nathan C. Pickles to San Francisco and to Manila, P. I., about Jan. 5, for duty.

Majs. Thomas C. Daniels and James I. P. Irwin from duty in Philippine Department to United States and report for instructions.

The following honorary discharged as colonels only: Majs. Ireslie D. Baskin and William C. Webb, Jr.

Capt: Waldo J. Adams to Whipple Barracks, Ariz., general hospital 20, for duty.

Capt. Merle W. Catterlin to Fort Sheridan, III., general hospital 28, for duty.

Capt. Julius Link Bishof to Denver, Colo., general hospital 21, for duty.

Capt. Solomon J. Z. Gantz to Camp Lewis, Wash., for duty.

Capt. Leroy T. Asche to Governors Island, N. Y., for duty.

-Army and Navy Register, December 13. 
Capt. Warren C. Caldwell report by wire to commanding general Southern Department, for duty.

Capt. Alexander M. Smith, Jr., to Fort Bliss, Tex., base hospital for duty.

-Army and Nayy Register, December 20.

Maj. Benjamin C: Warfleld, report by wire to commanding general Northeastern Dèpartment for assignment.

First Lieut. Arthur F. Bokman, to Columbus barracks, ohio, for duty.

- Army and Navy Rezister, December 27.

Lieut. Col. George I. Gunckel (promoted subject to examination), having been examined for promotion by a board of officers, and found physically disqualified for the duties of a lieutenant colonel in dentai corps, by reason of disability incident to the service, his retirement from active service as a lieutenant colonel is announced; proceed home.

The following to San Francisco and to Vladivostok, Siberia, Jan. 5, for duty; Lieut. Col. John R. Ames, Capts. Claude R. Hollister, Edward C. Alley, First Lieuts. George M. Krough and Chester B. Parkinson.

Maj. Frederick R. Wunderlich fnom duty with American expeditionary forces, Vladivostok, Siberia, to United States and report for instructions.

Capts. Daniel Bratton, Oscar W. Thompson to Camp Zachary Taylor, Ky., for duty.

First Lieut. Henry A. Winslow to general hospital 2, Fort McHenry, Md., for duty.

-Army and Navy Register, January 3.

- Maj. Charles M. Taylor to Walter Reed General Hospital, D. C., for duty.

Maj. William D. White to Alcatraz, Calif., disciplinary barracks for duty.

Maj. Earle J. McClung report by wire to comnanding general Western Department for assignment to duty.

Maj. Robert R. Luce, honorably discharged.

Capt. Joseph L. Rahm to Arcadia, Calif., Ross Field, for duty.

Capt. John L. Davis to Camp Upton, N. Y., for duty.

Capt. Leon M. Muedeking to Fort Sheridan, Ill., general hospital 28, for duty.

First Lieut. Herbert E. Guthrie to San Antonio; Tex., Kelly Field for duty.

-Army and Navy Register, January 10.

The resignation of Maj. F. Henry Valentine is accepted.

Maj. David Archibald Proctor and First Lieuts. George Robson White and William Alfonso Baker are honorably discharged.

Capt. Arthur Clay Foard to Walter Reed General Hospital, Washington, for duty.

First Lieut. Henry. Lake Gilmour, Jr., to Camp A. A. Humphreys, Va., for duty.
Appointment of Clark Wayne Russell as first lieutenant, dental corps, Regular Army, from Oct. 28, 1919, is announced; to Fort Logan, Colo., for duty.

Appointment of Joseph Aloysius Murray as first lieutenant, dental corps, Reguar Army, from Oct. 30, 1919, is announced'; to Camp Dix, N. J., for duty.

Appointment of Forest Vernon Bockey as first lieutenant, dental corps, Regular Army, from Oct. 30,1919 , is announced; to report to commanding general, American Forces in Siberia, for duty.

Appointment of James Lawrence Olsen as first lieutenant, dental corps, Regular Army, from oct. 31, 1919, is announced; to Camp Meade, Md., for duty.

Appointment of Alexander MacKenzie Telfer as first, lieutenant, dental corps, Regular Army, with rank from Nov. 1, 1919, is announced; to Walter Reed General Hospital, Washington, for duty.

Appointment of Clyde Wakefield Scogin as first lieutenant, dental corps, Regular Army, from Nov. 3, 1919, is announced; to Alcatraz, Calif., disciplinary barracks for duty.

The following temporary officers of the dental corps have been appointed first lieutenants, dental corps, Regular Army: Capt. Page Purnell Albert Chesster, Oct. 25, 1919 ; First Lieut. Ralph Eugene Morgan, Oct. 26, 1919 ; First Lieut. Joseph Hayden Jones, Oct. 29, 1919; First Lieut. Glenn Dale Lacey, Oct. 31, 1919; First Lieut. Harold Snell Whitney, Nov. 1, 1919; First Lieut. Egbert Wesley van Delden Cown, Nov. 2, 1919; Capt. Beverley Morrison, Epes, Nov. 4, 1919; Capt. Warren Charles Caldwell, Nov. 4, 1919.

-Army and Navy Register, January 17. duty.

Maj. Oscar P. Snyder to Camp Grant, Ill., for

Maj. Rex McK. MCDowell to Washington and report to director of purchase and storage for duty.

Maj. Nathaniel Barnard to Jefferson Barracks, Mo., for duty.

The resignation by Homer L. Sams, dental corps, as temporary captain and as first lieutenant. (Regular Army) accepted.

1st Lieut. Clyde W. Scogin to Denver, Colo., general hospital 21, for duty.

Ist Lieut. Robert C. Craven to Camp Grant, Ill., for duty.

Ist Lieut. Earl G. Gebhardt to Camp Grant, Ill., for duty.

- Army and Navy Register, January 24. DENTAL CORPS.

Resignation by Maj. Ben H. Sherrard accepted."

Capt. Thomas M. Page, to Camp Jackson, s."C., for duty:

1st Lieut. Clyde W. Scogin, to fort McDowell, Calif., for duty.

1st Lieut. Frank R, Gould, honorably discharged. -Army and Navy Register, January 31. 